\title{
Short communication: Variations in leaf morphological characters of Shorea leprosula in progeny trial stand of a logging concession in Kalimantan, Indonesia
}

\author{
ALNUS MEINATA, MUHAMMAD NA'IEM, DWI TYANINGSIH ADRIYANTI \\ Faculty of Forestry, Universitas Gadjah Mada. Jl. Agro No. 1, Bulaksumur, Sleman 55281, Yogyakarta, Indonesia. Tel./fax.: +62-274-550541, \\ "email: dtadrianti@ugm.ac.id, meinataa@gmail.com
}

Manuscript received: 14 September 2021. Revision accepted: 27 October 2021.

\begin{abstract}
Meinata A, Na'iem M, Adriyanti DT. 2021. Short communication: Variations in leaf morphological characters of Shorea leprosula in progeny trial stand of a logging concession in Kalimantan, Indonesia. Biodiversitas 22: 5097-5105. Indonesia has the largest diversity and highest distribution of Dipterocarpaceae members, and Shorea leprosula is one of the species that has a natural hybrid in its habitat. This species has intermediate morphological characters with the neighboring species Shorea curtisii, suggesting there might be a possibility of outbreeding across dipterocarps species. This study aimed to investigate the morphological variations of the leaf of Shorea leprosula Miq. progeny trial in a logging concession in Kalimantan, Indonesia. The morphological characters of $72 S$. leprosula individuals in the progeny trial stand were identified through sampling. Macroscopic and microscopic observations were conducted, and the measurement data of 22 characters were analyzed using clustering and principal component analyses to explain the similarity pattern and the contribution of each morphological character. The results showed variations in four characters, namely laminar shape, apex shape, base shape and midrib thickness. The cluster analysis classified the samples into four cluster groups, namely (i) a notophyll leaf size category with a rounded base; (ii) a laminar ellipse shape with medium midrib thickness; (iii) an oblong laminar with an obtuse apex shape; (iv) a notophyll leaf size category with an obtuse base. The principal component analysis showed that the base shape had the highest contribution to the variation of the samples.
\end{abstract}

Keywords: Adaptation, Dipterocarpaceae, leaf architecture, morphology, variation

\section{INTRODUCTION}

Indonesia has the highest distribution of Dipterocarpaceae with 400 species of a total of 506 species globally (Dayanandan et al. 1999). The dipterocarps (plant under the Dipterocarpaceae family) play an important role in the ecological and economic sectors of the country (Ghazoul 2016). Among the dipterocarp group in Indonesia, Shorea leprosula Miq., which is locally known as light red meranti and belongs to the Mutica division, is considered an important species. S. leprosula has geographical distribution across Southern Thailand, Peninsular Malaysia, Sumatra, and Borneo Island (Ashton 1982). This species is commonly found in lowland forests, swamp forests and heath forests below 700 above sea level (Purwaningsih 2004). It is considered a fast-growing meranti with a diameter increase of more than $2 \mathrm{~cm} /$ year when treated with intensive forestry practice (Soekotjo 2009; Widiyatno et al. 2013). S. leprosula has class II-IV and III-IV strength and durability index, making it suitable for a wide range of uses, such as boat making, furniture and building construction (Ashton 1982; Wahyudi and Sitanggang 2016; Wistara et al. 2016).

Some Dipterocarpaceae members have the same pollinators (e.g., Thrips spp.), so that there is a possibility of outbreeding across dipterocarps species (Appanah 1993; Ashton 1982). Furthermore, similar periods of flowering have been reported for $S$. leprosula and its neighboring species Shorea curtisii (Kamiya et al. 2011). Such phenomenon might be related to the intermediate morphological characters in the $S$. leprosula as hypothesized by Kamiya (2011), although empirical evidence that can explain such variations in the habitat is scarce.

Variation is the response of plants to their environment with regard to their genetic traits (Bruce, 2014) and it identifies crucial potential taxonomic novelty in the breeding studies (Forster 2014). Studies on leaf architecture are significantly important in taxonomy, particularly to identify species without a generative organ (Lu et al. 2012; Martínez-Cabrera et al. 2009). Leaf architecture has been widely studied, and it is one of the approaches in taxonomy to separate Terminalia spp. member (Jessica and Buot Jr. 2014) to distinguish two confusing species (Villareal and Buot Jr. 2015). Therefore, an in-depth study of the variation of leaf architecture specifically within the species (intraspecific variation) can be conducted to understand the genetic adaptation of plant to the environment (Anderson et al. 2011).

This study aimed to identify variation in leaf morphological character of $S$. leprosula in progeny trial stand of a logging concession in Kalimantan and identify the character that significantly delineate the variations. We expected the results of this study could contribute to further breeding studies as baseline morphological variation data. 


\section{MATERIALS AND METHODS}

\section{Study area}

This study was conducted in a logging concession located in between West Kalimantan and Central Kalimantan Provinces (Figure 1). The northern part was bordered by the Protection Forest (Hutan Lindung) under the authority of the provincial government, while the southern and eastern part was bordered by another logging concession and Bukit Baka Bukit Raya National Park. The western part was bordered by two logging concessions (Haebahan 2017). Based on the Schmidt-Fergusson, the studied area is classified into the climate type A category with precipitation $282 \mathrm{~mm} /$ month and average rainy days of 12 days per month. The average temperature ranges between $22-28^{\circ} \mathrm{C}$ at night, and $30-33^{\circ} \mathrm{C}$ in the daytime (Paisey 2009).

\section{Procedures}

\section{Leaf collection}

The collection of leaves was conducted from 24 February to 4 March 2021 at the progeny stand, which was established in 2002 with four tree plots in each seed lot (Haebahan 2017). The seed lot was rogued until the best tree plot remained, and the remaining 72 tree plot were sampled three-leaf blades on each tree plot and conducted the observation. The mature leaves, the seventh leaf from the terminal shoot were selected to be characterized (Meinata et al. 2021) and were stored in newspaper and dried under the sun periodically. Furthermore, the paper was changed every six hours to prevent rotting. After the drying process, the leaves were stored in an air thigh bag to prevent damage caused by bugs or fungi during transportation.

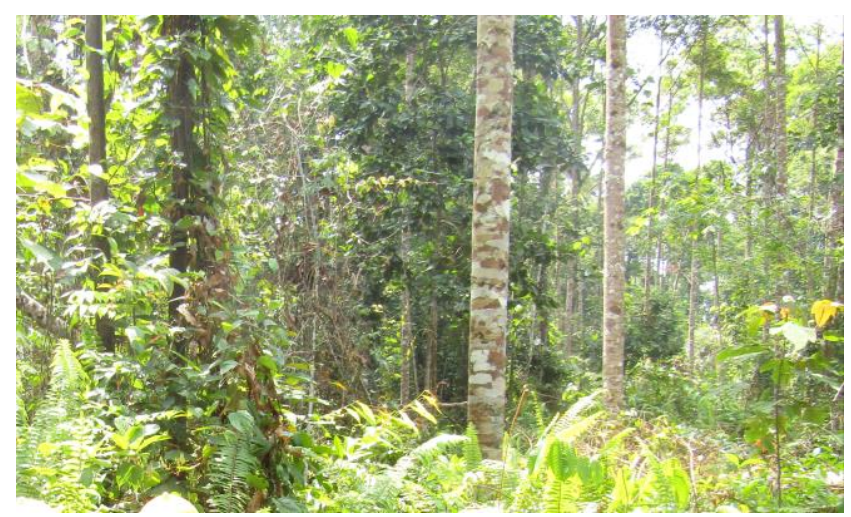

Figure 2. Shorea leprosula progeny stand

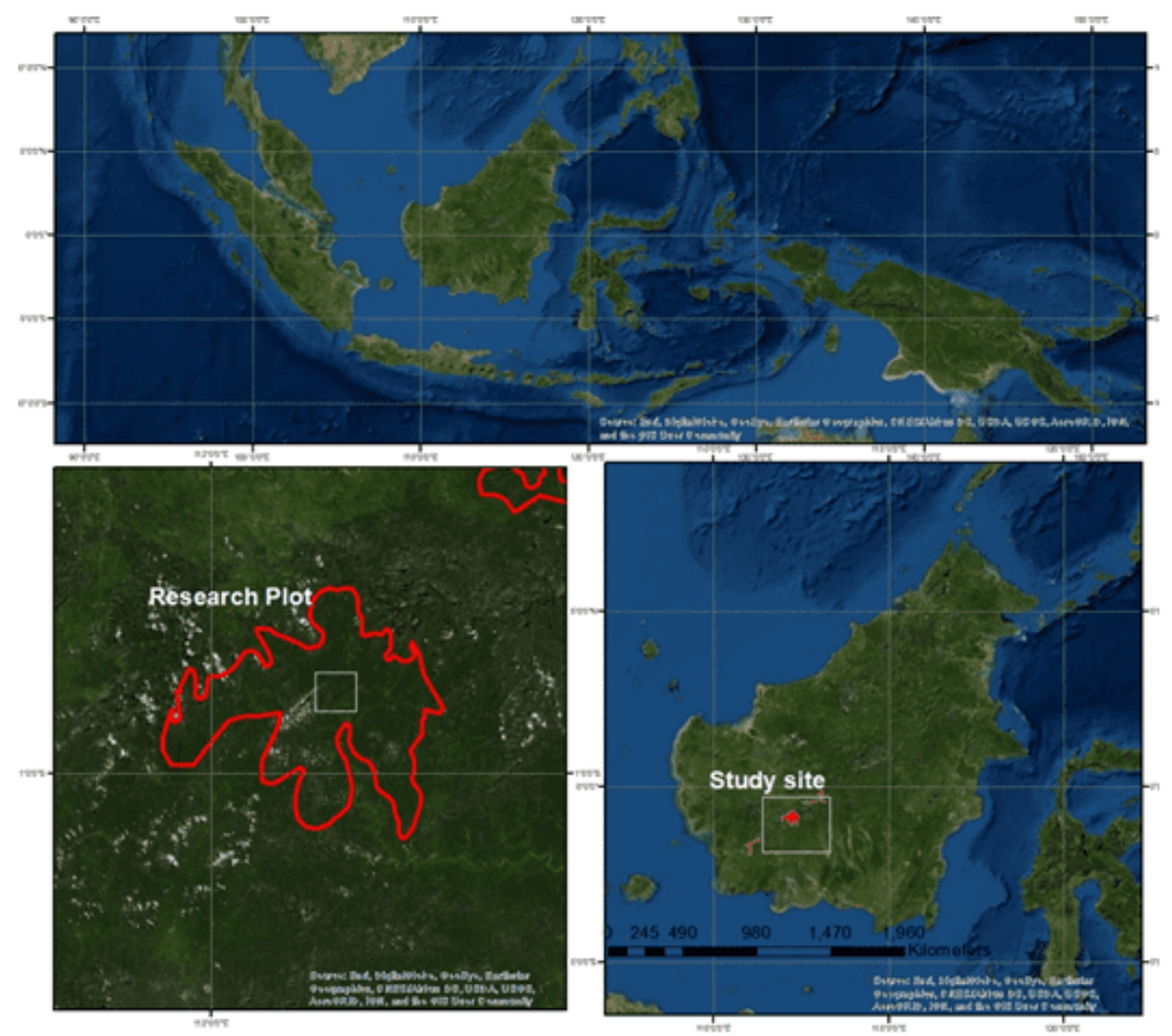

Figure 1. Map of the study area in a logging concession in in between West Kalimantan and Central Kalimantan Provinces, Indonesia 


\section{Leaf observation}

There was 216 leaf blade sampled from the field collection. The leaf was observed by putting it on millimeter block paper to measure the scale of the image. The observation started with macroscopic measurement, including leaf area, laminar shape, laminar symmetry, base shape, apex shape, leaf surface, leaf texture, and leaf margin. Furthermore, microscopic characterization was conducted by cutting the leaf into $1 \times 1 \mathrm{~cm}$ size. The cut area was put in the middle, and the margin and midrib parts were used to observe the midrib and marginal venation category. The microscopic leaf category describes venation order, areolation, free ending ultimate vein, marginal ultimate vein, midrib thickness, and hairiness. The microscopic character observed using the leaf clearing process is consistent with protocols modified by Schmid and Ruzin (1999). Then, the trimmed leaf was digested in $\mathrm{NaOH} 10 \%$ solution for 12 hours and was rinsed with aquadest three times. After rinsing, the sample was being digested by $\mathrm{NaOCl} 5.25 \%$ solution to dissolve the tissues until the sample became transparent and whitish. The sample was then rinsed in aquadest for 15 minutes to remove the $\mathrm{NaCl}$ residue, and the leaf was dyed with safranin and mounted in cover glass sized $24 \mathrm{~mm}$ x $66 \mathrm{~mm}$. Each glass was given a label, and a microscopic examination was conducted for a more detailed description.

\section{Leaf characterization}

The scoring was conducted based on the visible leaf architecture. The following scores were given to be used in clustering analysis and to explain the certain character among the possible created group.

\section{Data analysis}

The variation in leaf characters was described and analyzed using Multivariate Statistical Package 2.1. Gower Similarity Coefficient and the clustering algorithm were used with Unweighted Pair Group Method and Arithmetic Means (UPGMA). Gower similarity coefficient was used to analyze the delineation since the study contained categorical data (Hadi 2018; Onda and Uot 2018). Furthermore, the principal component analysis was performed to identify the investigated variables that contribute to the variation.

\section{RESULTS AND DISCUSSION}

\section{Leaf morphological variation}

Several morphological characters had variations among individuals, for instance, the laminar size which was determined by multiplying leaf length and width by $2 / 3$ (Hickey et al. 1999). The observation showed that the sampled leaves had three-leaf size categories, i.e., microphyll (225-2,025 $\left.\mathrm{mm}^{2}\right)$, notophyll (2,2025-4500 $\mathrm{mm}^{2}$ ), and mesophyll (4,500-18,225 $\mathrm{mm}^{2}$ ) (Figure 2). The leaf size range in a species is influenced with the environmental condition (Garnier et al. 2016), and it is known as a plastic morphological character that produces plant genetic-environment response that is important in the taxonomic study (Sack and Scoffoni 2013). The majority of the sampled individuals had the notophyll leaf category, two individuals had the microphyll category and two others had the mesophyll category. The results showed that there are variations in the site which cause different morphological conditions. Since the variation was small, deeper observation on the site is necessary to ensure the factors affecting leaf size variation.

Table 1. Leaf architecture variation in Shorea leprosula scoring table

\begin{tabular}{|c|c|}
\hline Leaf character & Score \\
\hline Size category & $1=$ mesophyll; $2=$ notophyll; 4 = microphyll \\
\hline Laminar shape & $1=$ elips $; 2=$ oblong; $3=$ obovate $; 4=$ ovate \\
\hline Laminar symmetry & $1=$ symmetrical; $2=$ assymetrical \\
\hline Base shape & $1=$ rounded $; 2=$ truncate $3=$ acute $; 4=$ obtuse \\
\hline Apex shape & $1=$ rounded $; 2=$ acute $; 3=$ acuminate $; 4=$ obtuse \\
\hline Leaf surface & $1=$ smooth $; 2=$ rough \\
\hline Leaf texture & $1=$ thinly coriaceous $; 2=$ rigid $; 3=$ fleshy coriaceous $4=$ fleshy coriaceous $5=$ coriace \\
\hline $1^{\circ}$ vein & $1=$ pinnate $2=$ others \\
\hline $2^{\circ}$ vein & $1=$ brochidodromous $; 2=$ weak brochidodromous; $3=$ eucamptodromous \\
\hline $3^{\circ}$ vein & $1=$ oppsite precurrent; $2=$ alternate precurrent \\
\hline Vein course & $1=$ straight $; 2=$ convex $; 3=$ sinous \\
\hline $4^{\circ}$ vein & $1=$ oppsite precurrent; 2 = alternate precurrent \\
\hline $5^{\circ}$ vein & $1=$ regular polygonal reticulate $2=$ dichotomizing \\
\hline Areolation & 1 = well developed; 2 = poorly developed \\
\hline Free ending ultimate vein & $1=$ present $; 2=$ absent \\
\hline Marginal Ultimate vein & $1=$ present $2=$ absent \\
\hline Midrib thickness & $1=$ thin $; 2=$ medium $; 3=$ thick \\
\hline Laminar hair & $1=$ present $; 2=$ absent \\
\hline Midrib hair & $1=$ present $2=$ absent \\
\hline Margin hair & $1=$ present $2=$ absent \\
\hline Laminar margin & $1=$ entire $2=$ lobed \\
\hline
\end{tabular}


The sample had variations in laminar shape, which were ellipse, oblong, ovate, and obovate (Figure 3). Ellipse laminar shape and oblong category comprised about 40 and 28 samples, respectively, while the ovate and obovate category consisted of 3 and 1 samples. The laminar shape is one of the significant descriptors in taxonomy to delineate one species to another (Khadivi-Khub and Anjam 2014). The variation is originated from auxin transport in the leaf vascular at early development (Harrison and Morris 2018). Furthermore, the auxin and vein formation determine the leaf axis and guide where the tissues will grow. Leaf shape variation occurs as the response of plants to the environment which alters the physiological and morphological characters of the plant (Striker 2012) along with genetic factors (De Kort et al. 2021).

There were four types of leaf apex characterized from the samples, namely rounded, acuminate, acute and obtuse, and it represented the $1 / 4$ of the upper leaf part measured from the base (Figure 4). On the other hand, base shape variation showed four different shapes, which were rounded, acute, truncate, and obtuse (Figure 5).

There was also variation in midrib thickness, and it was categorized as thin $(0.3-0.8 \mathrm{~mm})$, medium $(0.8-1.3)$, and thick (1.4-1.8). Midrib contains a vascular bundle that transports water and mineral as well as photosynthesis and carbon fluxes (Sack and Scoffoni 2013). Leaf venation provides a defensive function and may influence whole plant carbon production processes (Onoda et al. 2012).

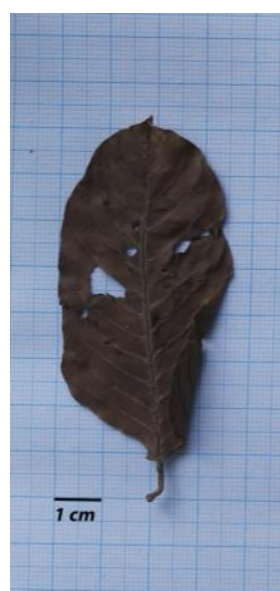

A

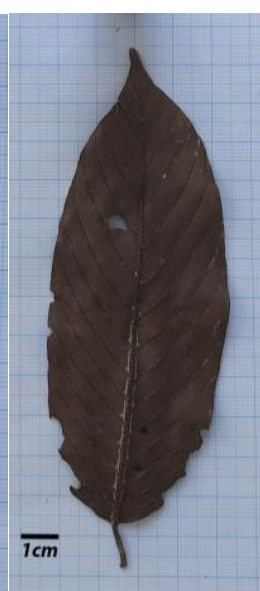

B

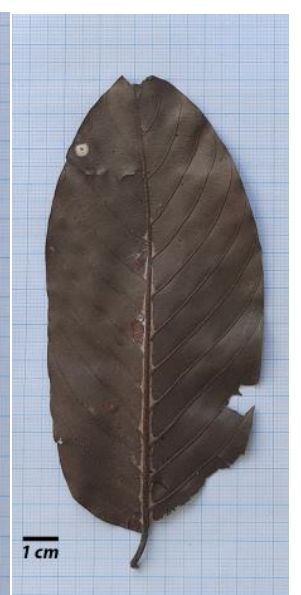

C
Figure 3. Three laminar size categories in Shorea leprosula progeny trials characterized in this study: A. microphyll; B. notophyll; C. mesophyll

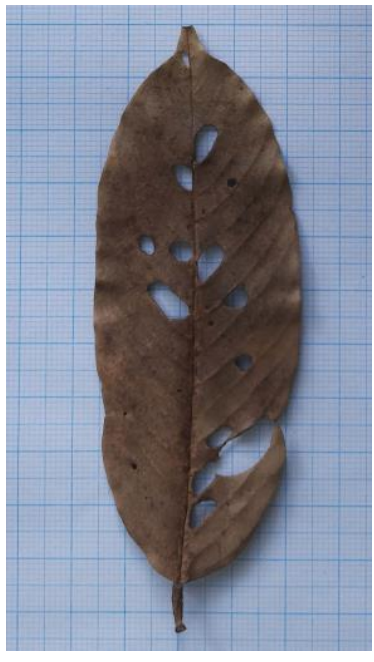

A

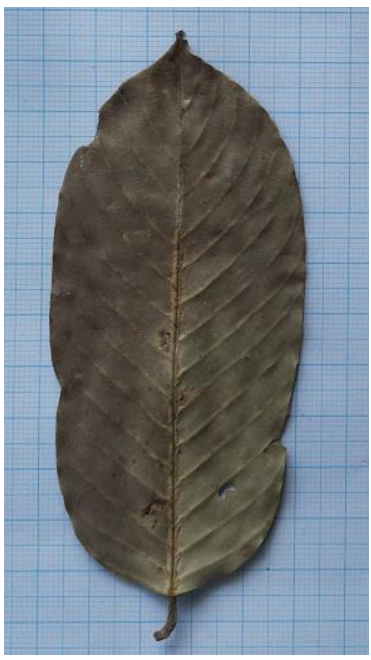

B

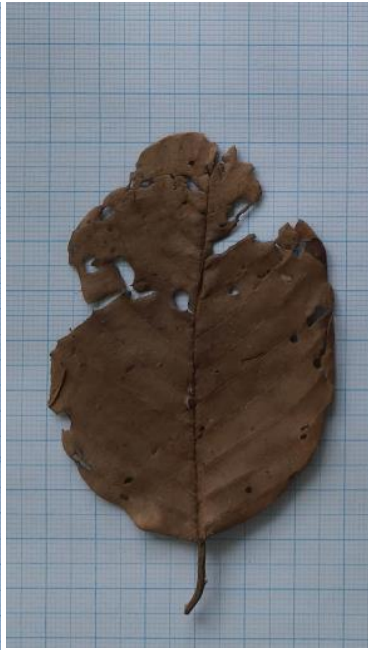

C

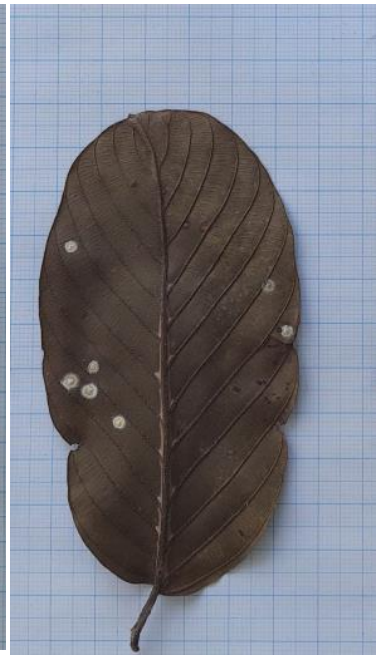

D

Figure 4. Laminar shape variation in Shorea leprosula progeny trials characterized in this study: A. ellipse; B. oblong; C. ovate; D. obovate

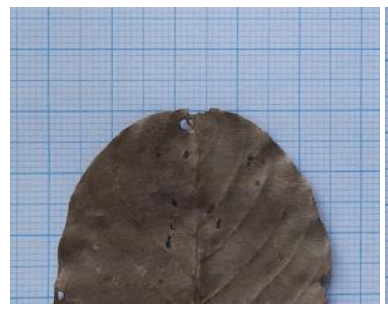

A

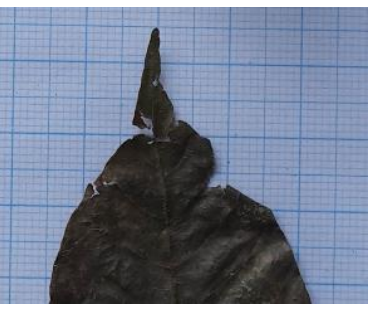

B

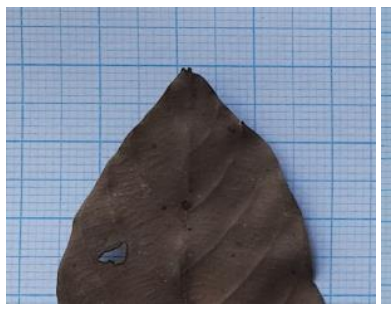

C

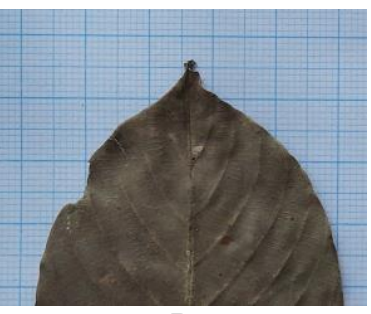

D

Figure 5. Four leaf apex variation in Shorea leprosula progeny trials characterized in this study: A. rounded; B. acuminate; C. acute; D. obtuse 


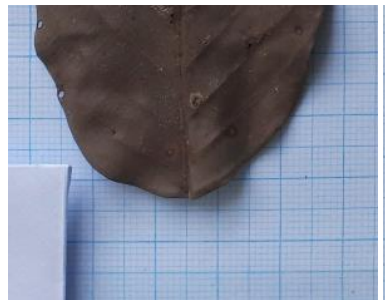

A

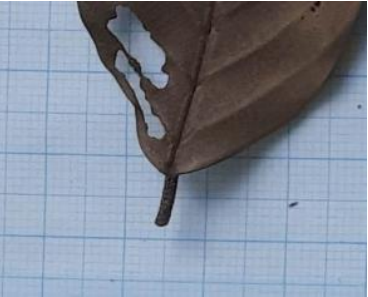

B

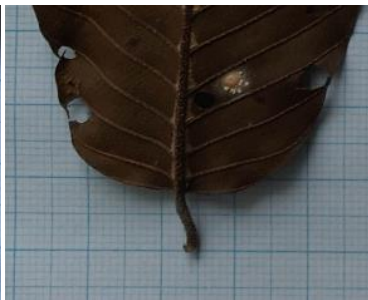

C

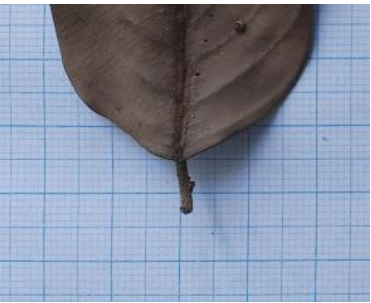

D

Figure 6. Four leaf base variation in Shorea leprosula progeny trials characterized in this study: A. rounded; B. acute; C. truncate; D. obtuse

However, not all of the descriptors had variation and this was the case of venation order. The observation result showed that the $1^{\circ}$ vein category remains pinnate in all samples. Pinnate type $1^{\mathrm{o}}$ vein is when there is only one main midrib. Physiologically, it has the highest photosynthetic activity due to its transport function. Also, it has the densest venation compared to palmate and parallel venation (Sack and Scoffoni 2013), and it represents high biomass storage on the leaf (Hardiman et al. 2013). The results of $2^{\circ}$ vein observation showed that all samples had a weakly brochidodromous type. This is due to the upward looping of the secondary vein with a weak joint between its upper venation. In terms of species delineation, the $2^{\circ}$ vein has a strong significance in several studies such as the results obtained from Sapotaceae and Malvaceae (Hussein et al. 2021). This has been proven to separate two different genera in Dipterocarpaceae, i.e. Hopea and Dryobalanops (Meinata et al. 2021).

Microscopic observation also showed that there was no variation in other venation orders. The $3^{\circ}$ vein is the primary branch of the $2^{\circ}$ level, and all the samples showed the opposite percurrent type of the $3^{\circ}$ vein category. The tertiary vein was shown to have one straight vein connecting the $2^{\circ}$ without branches (Figure 6). Other studies found that the $3^{\circ}$ vein category is proven to significantly distinguish the Cinnamomum spp. (Celadiña et al. 2012; Lillo et al. 2019). The category also shares the same course, and it is straight without any major curves in connecting the $2^{\circ}$ vein.

The $4^{\circ}$ vein venation had the same category with an alternate percurrent (Figure 7). It showed that the vein connecting the $3^{\circ}$ venation is not directly straight but slightly dichotomized (Doyle 2007). The $4^{\circ}$ vein is considered as minor venation support in the transportation and mechanical function of the plant (Blonder et al. 2011). It delivers nutrient and photosynthesis material to the mesophyll tissues (Palgano and Storchi 2016).

The results of the $5^{\circ}$ vein category showed that all samples shared one character, that is regular polygonal reticulate, and the areolation from all samples was categorized as well-developed (Figure 8). This type of category has polygonal reticulate that connect each other and form an approximately constant shape.
The samples had a uniform free ending and marginal ultimate vein (Figure 9). The free ending ultimate vein was not joined with the leaf margin. Meanwhile, the marginal ultimate vein describes the shape of the vein in the marginal part of the leaf. The marginal ultimate vein is classified as fimbrial when the smaller venation is joined with the larger vein.

\section{Cluster analysis}

The clustering analysis was applied to identify the shared characters and the delineators of each individual. There were 22 characters used as clustering variables which have been widely used to identify the variations in taxa. Furthermore, the similarity between samples was analyzed by Gower Similarity Coefficient. It showed that the similarity index and the possibility of the sample being closely related are directly proportional. The result of clustering analyses showed that the similarity index ranged from 0.904-0.990. Although the similarity index indicates that the variation in the field is subjectively low in, however the observed sample belonged to single species where a slight variation will show that the plant has different responses in the environment (Maggs-Kölling et al., 2000). The phenon lines were drawn in 0.931 to generate four clusters of species that share similar characters (Figure 10). The first group (i) consists of notophyll leaf size category with rounded base, the second (ii) group consists of ellipse laminar shape with medium midrib thickness, the third (iii) group with oblong laminar shape and obtuse apex shape, and the fourth (iv) group has notophyll leaf size category with obtuse base.

\section{Principal Component Analysis}

The variables that provided a significant contribution to the variation were analyzed in this study. The principal component analysis reduces the variable dimension without eliminating the characters already given. The principal component analysis was conducted using 22 characters. The result showed that the largest contribution was by base shape and the other characters had the lower contribution including as laminar size category, apex shape, and midrib thickness, respectively (Table 2). 


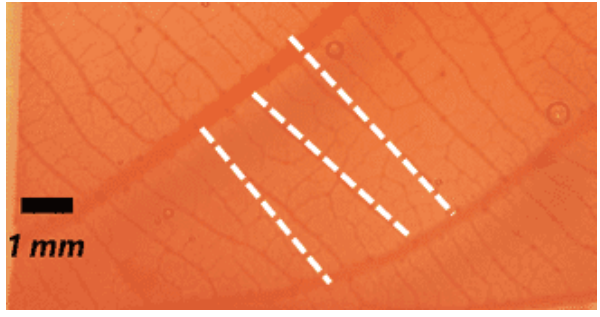

Figure 7. The $3^{\circ}$ vein category and 3 vein courses in Shorea leprosula progeny trials characterized in this study

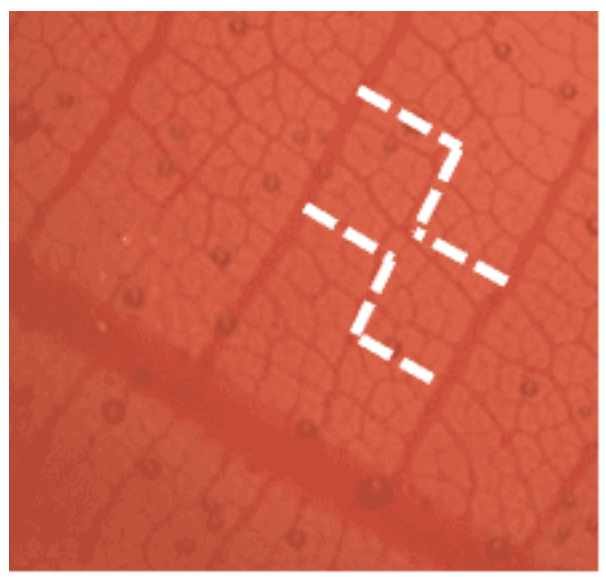

Figure 8. The $4^{\circ}$ vein category in Shorea leprosula progeny trials characterized in this study

Table 2. Result of Principal Component Analysis of leaf architecture variation in Shorea leprosula progeny trial in this study

\begin{tabular}{lcc}
\hline Character & Axis 1 & Axis 2 \\
\hline Size category & $\mathbf{1 . 7 9}$ & $\mathbf{0 . 0 7 9}$ \\
Laminar shape & $\mathbf{0 . 1 1 9}$ & $\mathbf{0 . 3 2 4}$ \\
Laminar symmetry & -0.313 & -0.005 \\
Base shape & $\mathbf{2 . 2 3 7}$ & $\mathbf{0 . 6 1 1}$ \\
Apex shape & $\mathbf{1 . 7 1 3}$ & $\mathbf{- 0 . 9 1 8}$ \\
Leaf surface & -0.313 & -0.005 \\
Leaf texture & -0.313 & -0.005 \\
$1^{\circ}$ vein & -0.313 & -0.005 \\
$2^{\text {o vein }}$ & -0.313 & -0.005 \\
$3^{\circ}$ vein & -0.313 & -0.005 \\
Vein course & -0.313 & -0.005 \\
$4^{\circ}$ vein & -0.313 & -0.005 \\
$5^{\circ}$ vein & -0.313 & -0.005 \\
Areolation & -0.313 & -0.005 \\
Free ending ultimate vein & -0.313 & -0.005 \\
Marginal Ultimate vein & -0.313 & -0.005 \\
Midrib thickness & $\mathbf{0 . 0 9}$ & $\mathbf{- 0 . 0 0 8}$ \\
Laminar hair & -0.313 & -0.005 \\
Midrib hair & -0.313 & -0.005 \\
Margin hair & -0.313 & -0.005 \\
Leaf margin & -0.313 & -0.005 \\
\hline
\end{tabular}

\section{Discussion}

The results showed variation in morphological characters of the leaf of $S$. leprosula progeny test in a logging concession in Kalimantan. There were four

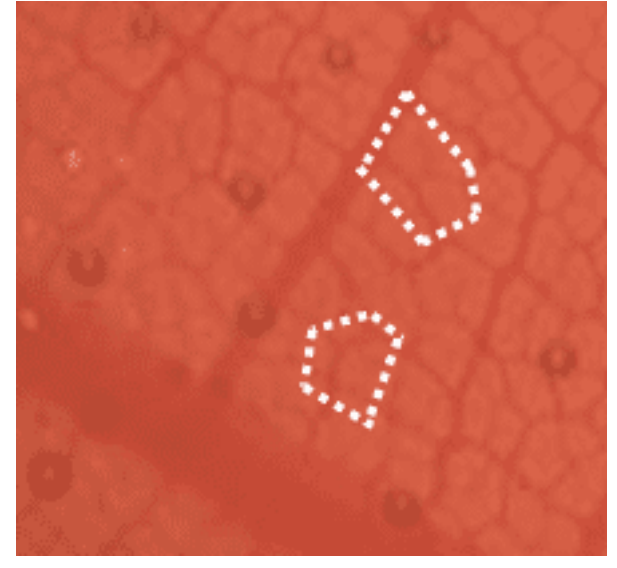

Figure 9. The $5^{\circ}$ vein category and areolation in Shorea leprosula progeny trials characterized in this study

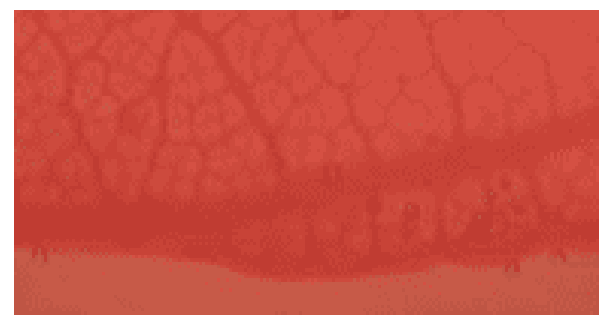

Figure 10. Marginal ultimate vein in Shorea leprosula progeny trials characterized in this study

characters of leaf architecture that varied, namely laminar shape, base shape, apex shape, and midrib thickness. An individual genotype affects particular characteristics in a given environment (Van Eeuwijk et al. 2016), and the amount by which the expressions of individuals are changed by different environments is a measure of the plasticity of these characters. Therefore, plasticity is influenced by a genotype while the expression is altered by environmental factors. The change that occurs can be termed as a plant response, and it applies to all intragenotype variabilities since changes in the characters of an organism that are not genetic are largely influenced by environmental factors.

One of the plasticity manifestations is a morphological variation as a response to genetics and environment, and this study indicated that variation in leaf architecture was shown to occur in leaf size and midrib thickness. The results also showed that leaf variation did not occur in the venation pattern. The problem of adaptation in a heterogeneous environment is solved by plasticity, which enables the plant to change its growth pattern after encountering different stresses. Furthermore, variation in size, such as the leaf, is critical to plant particularly to adapt with resource availability. As a photosynthetic organ, the leaf provides survivability for the plant, and this study showed that the variation in the progeny test of S. leprosula happens in certain characters only. This result strengthens the study that supports leaf architecture as a persistent character in a species (Meinata et al. 2021). 


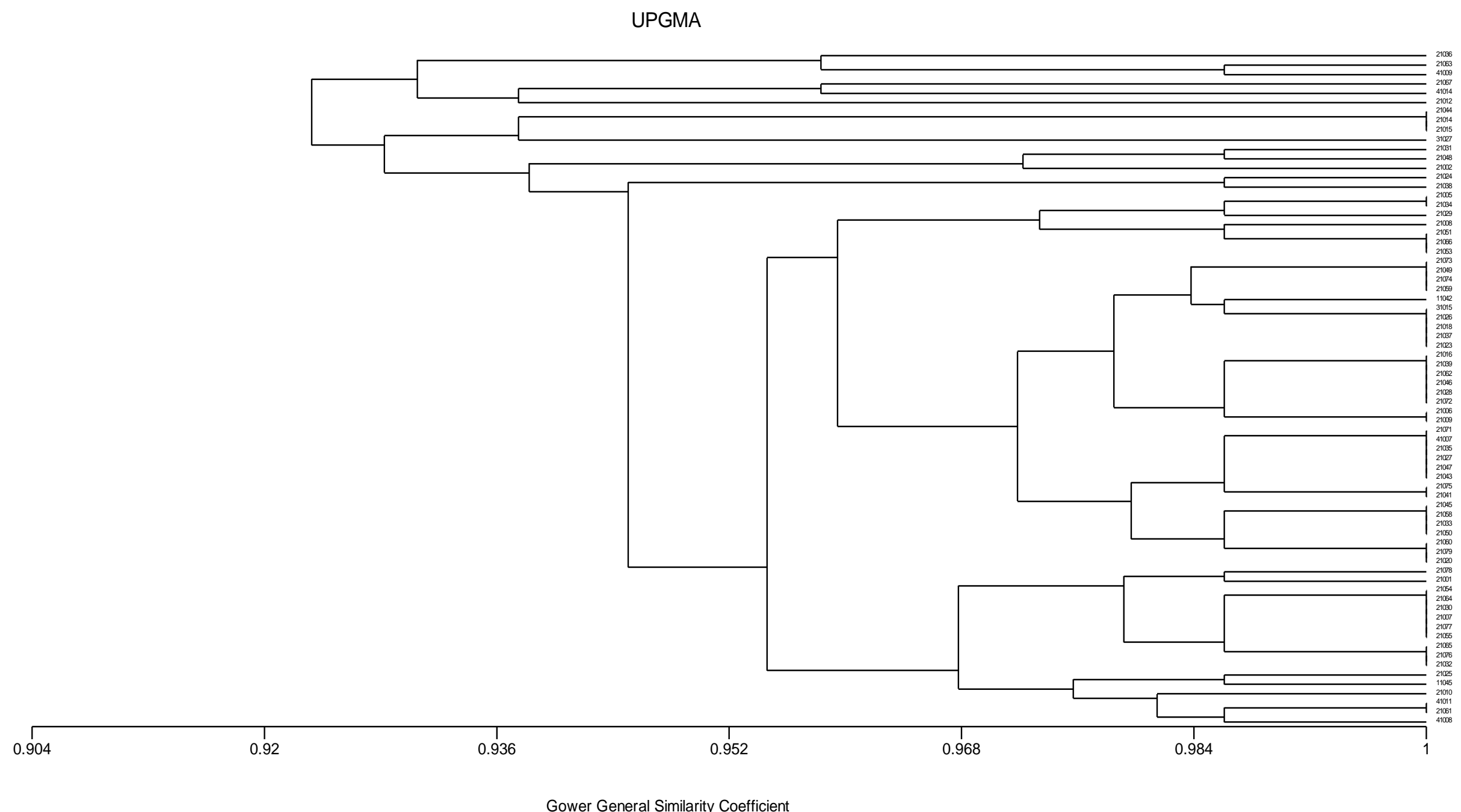

Figure 11. Cluster analysis of leaf architecture variation in Shorea leprosula progeny trial in this study 
In conclusion, the $S$. leprosula showed leaf architecture variations as its response to their environment in four characters, namely laminar shape, apex shape, base shape and midrib thickness. The cluster analysis classified the samples into four cluster groups, namely (1) a notophyll leaf size category with a rounded base; (ii) an laminar ellipse shape with medium midrib thickness; (iii) an oblong laminar with an obtuse apex shape; (iv) a notophyll leaf size category with an obtuse base. The principal component analysis showed that the base shape had the highest contribution to the variation of the samples. The finding suggests that $S$. leprosula variation reflect their wide range ability to adapt to their new environment and that mechanism possibly push the speciation process and species-site response adaptability.

\section{ACKNOWLEDGEMENTS}

The author is grateful to PT. Sari Bumi Kusuma for facilitating this study, and its staff of Purnomo, Jatmoko, and Antok for helping during data collection. Also, the author thank RTA (Thesis recognition) for funding this study.

\section{REFERENCES}

Anderson JT, Willis JH, Mitchell-Olds T. 2011. Evolutionary genetics of plant adaptation. Trends Genet 27 (7): 258-266. DOI: 10.1016/j.tig.2011.04.001.

Appanah S. 1993. Mass flowering of dipterocarp forests in the aseasonal tropics. J Biosci 18 (4): 457-474. DOI: 10.1007/BF02703079.

Ashton PS 1982. Dipterocarpaceae. In: van Steenis CGGJ (ed) Flora Malesiana (9): 237-552.

Blonder B, Violle C, Bentley LP, Enquist BJ. 2011. Venation networks and the origin of the leaf economics spectrum. Ecol Lett 14 (2): 91100. DOI: 10.1111/j.1461-0248.2010.01554.x.

Bruce TJ. 2014. Variation in plant responsiveness to defense elicitors caused by genotype and environment. Front Plant Sci 5, 349. DOI: 10.3389/fpls.2014.00349

Celadiña DA, Buot Jr IE, Madulid DA, Evangelista TT, Tandang DN 2012. Leaf architecture of selected Philippine Cinnamomum Schaeff. (Lauraceae) Species. Thail Nat Hist Mus J 6 (2): 89-111.

Dayanandan S, Ashton PS, Williams SM, Primack RB. 1999. Phylogeny of the tropical tree family Dipterocarpaceae based on nucleotide sequences of the chloroplast rbcL gene. Am J Bot 86 (8): 1182-1190. DOI: $10.2307 / 2656982$.

De Kort H, Prunier JG, Ducatez S, Honnay O, Baguette M, Stevens VM, Blanchet S. 2021. Life history, climate and biogeography interactively affect worldwide genetic diversity of plant and animal populations. Nat Commun 12 (1): 1-11. DOI: 10.1038/s41467-021 20958-2.

Doyle JA. 2007. Systematic value and evolution of leaf architecture across the angiosperms in light of molecular phylogenetic analyses. CFS Cour. Forschungsinstitut Senckenb.

Forster BP, Till BJ, Ghanim AMA, Huynh HOA, Burstmayr H, Caligari PDS. 2014. Accelerated plant breeding. Cab Rev 9 (43): 1-16. DOI: 10.1016/j.tplants.2013.09.001.

Garnier E, Grigulis K. 2016. Plant Functional Diversity: Organism Traits, Community Structure, and Ecosystem Properties. Oxford University Press, UK. DOI: 10.1093/acprof:oso/9780198757368.001.0001.

Ghazoul J. 2016. Dipterocarp Biology, Ecology, and Conservation. Oxford University Press, UK. 10.1093/acprof:oso/9780199639656.001.0001.

Hadi MN. 2018. Keanekaragaman spesies dan hubungan kekerabatan fenetik Caesalpinia L. di Pulau Jawa Berdasarkan Anatomi dan
Venasi Daun. [Thesis]. Universitas Gadjah Mada. Yogyakarta, Indonesia. [Indonesian]

Haebahan K. 2017. Evaluasi Uji Keturunan Shorea leprosula Miq Populasi Bukit Baka dan Gunung Bunga di PT Sari Bumi Kusuma, Kalimantan Tengah. [Thesis]. Universitas Gadjah Mada. Yogyakarta, Indonesia. [Indonesian]

Hardiman BS, Gough CM, Halperin A, Hofmeister KL, Nave LE, Bohrer G, Curtis PS. 2013. Maintaining high rates of carbon storage in old forests: A mechanism linking canopy structure to forest function. For Ecol Manag 298, 111-119. DOI: 10.1016/j.foreco.2013.02.031.

Harrison CJ, Morris JL. 2018. The origin and early evolution of vascular plant shoots and leaves. Philos Trans R Soc B: Biol Sci 373 (1739). DOI: $10.1098 /$ rstb.2016.0496.

Hickey L, Ash A, Ellis B, Johnson K, Wilf P, Wing S. 1999. Manual of Leaf Architecture.

Hussein BR, Malik OA, Ong WH, Slik JWF. 2021. Reconstruction of damaged herbarium leaves using deep learning techniques for improving classification accuracy. Ecol Inform 61, 101243. DOI: 10.1016/j.ecoinf.2021.101243.

Jessica B, Buot Jr. IE. 2014. Leaf architecture of ten species of Philippine Terminalia Linn (Combretaceae). Intl Res J Biol Sci 3 (3): 83-88.

Kamiya K, Gan YY, Lum SKY, Khoo MS, Chua SC, Faizu NNH. 2011. Morphological and molecular evidence of natural hybridization in Shorea (Dipterocarpaceae). Tree Genet Genomes 7 (2): 297-306. DOI: 10.1007/s11295-010-0332-8.

Khadivi-Khub A, Anjam K. 2014. Morphological characterization of Prunus scoparia using multivariate analysis. Plant Syst Evol 300 (6): 1361-1372. DOI: 10.1007/s00606-013-0967-7.

Lillo E, Buot Jr. IEB, Malaki AB, Alcazar SMT, Rosales R, Diaz JLB, Redoblado BR, Gealon GGG. 2019. Short communication: Leaf architectural characteristics of Cinnamomum cebuense Kosterm. (Lauraceae) distributed in different geographical locations, taxonomic identification and conservation concerns. Biodiversitas J Biol Divers 21 (1): 246-251. DOI: 10.13057/biodiv/d210132.

Lu H, Jiang W, Ghiassi M, Lee S, Nitin M. 2012. Classification of Camellia (Theaceae) species using leaf architecture variations and pattern recognition techniques. PloS One 7 (1): e29704. DOI: 10.1371/journal.pone.0029704.

Maggs-Kölling, GL, Madsen, S, Christiansen, JL. 2000. A phenetic analysis of morphological variation in Citrullus lanatus in Namibia. Genet Resour Crop Evol 47 (4)" 385-393. DOI: 10.1023/A:1008751319879.

Martínez-Cabrera D, Terrazas T, Ochoterena H. 2009. Foliar and petiole anatomy of tribe hamelieae and other Rubiaceae. Ann Missouri Bot Gard 96 (1): 133-145. DOI: 10.3417/2006196.

Meinata A, Na'iem M, Adriyanti DT, Syahbudin A. 2021. Leaf architecture of 35 species of Dipterocarpaceae cultivated in forest area with special purposes in Carita, Banten, Indonesia. Biodivers J 22 (7): 2952-2960. DOI: 10.13057/biodiv/d220748.

Onda JEMC, Uot INEB. 2018. Species delineation of the Genus Diplazium Swartz (Athyriaceae) using leaf architecture characters. Bangladesh J Plant Taxonomy 25 (2): 123-133. DOI: 10.3329/bjpt.v25i2.39535

Onoda Y, Richards L, Westoby M. 2012. The importance of leaf cuticle for carbon economy and mechanical strength. New Phytol 196 (2): 441-447. DOI: 10.1111/j.1469-8137.2012.04263.x.

Pagano M, Storchi P. 2016. Leaf vein density and photosynthetic rate in Rosa: Is there a correlation?. Boletín de la Sociedad Argentina de Botánica 51 (4): 683-687. DOI: 10.31055/1851.2372.v51.n4.16357.

Purwaningsih. 2004. Ecological distribution of Dipterocarpaceae species in Indonesia. Biodivers J 5 (2): 89-95. DOI: 10.13057/biodiv/d050210.

Sack L, Scoffoni C. 2013. Leaf venation: Structure, function, development, evolution, ecology and applications in the past, present and future. New Phytol 198 (4): 983-1000. DOI: 10.1111/nph.12253.

Schmid R, Ruzin SE. 1999. Plant Microtechnique and Microscopy. Oxford University Press, New York. DOI: 10.2307/1224595.

Soekotjo. 2009. Teknik Silvikultur Intensif. Gadjah Mada University Press, Yogyakarta. [Indonesian]

Striker GG. 2012. Flooding stress on plants: anatomical, morphological and physiological responses. Botany 1, 3-28. DOI: 10.5772/32922.

Van Eeuwijk FA, Bustos-Korts DV, Malosetti M. 2016. What should students in plant breeding know about the statistical aspects of genotypex environment interactions?. Crop Sci 56 (5): 2119-2140. DOI: $10.2135 /$ cropsci2015.06.0375. 
Villareal AMM, Buot Jr IE. 2015. Leaf architecture of Hoya incrassata Warb. and Hoya crassicaulis Elmer x Kloppenb. (Apocynaceae) Taxonomic identification and conservation concerns. IAMURE Intl J Ecol Conserv 15 (1): 203-213. DOI: 10.7718/ijec.v15i1.1002.

Wahyudi I, Sitanggang, JJ. 2016. Wood quality of cultivated red meranti (Shorea leprosula Miq.). Jurnal Ilmu Pertaniam Indonesia 21 (2): 140-145. DOI: 10.18343/jipi.21.2.140. [Indonesian]

Widiyatno, Purnomo S, Soekotjo, Naiem M, Hardiwinoto S, Kasmujiono. 2013. The growth of selected Shorea spp. in secondary tropical rain forest: the effect of silviculture treatment to improve growth quality of Shorea spp. Proc Environ Sci 17: 160-166. DOI: 10.1016/j.proenv.2013.02.024

Wistara NJ, Sukowati M, Pamoengkas P. 2016. The properties of red meranti wood (Shorea leprosula Miq) from stand with thinning and shade free gap treatments. J. Indian Acad Wood Sci 13 (1): 21 32.DOI: 10.1007/s13196-016-0161-Y. 